\title{
How Soon Is Now: Constructing the Contemporary / Gendering the Experimental
}

The 2012 publication of the Routledge Companion to Experimental Literature, edited by Joe Bray, Alison Gibbons and Brian McHale, has renewed debates about the visibility or otherwise of experimental writing by women. Of the thirty seven chapters which make up this ambitious and wide-ranging volume, one is dedicated to writing by women and is placed alongside chapters exploring African American and postcolonial writing under the heading "Experiments with Identity." While the editors acknowledge the difficulty of defining a body of writing which is "irreducibly diverse" ("Introduction" 1), the largely formalist taxonomy which informs the organisation of this volume perhaps precludes consideration of the relationship between innovative literary practice and subversive politics which has been so central to feminist debates. This relationship is integral to the definition of experimental writing provided by Ellen G. Friedman and Miriam Fuchs in their landmark 1989 collection Breaking the Sequence: Women's Experimental Fiction:

In exploding dominant forms, women experimental writers not only assail the social structure, but also produce an alternative fictional space, a space in which the feminine, marginalized in traditional fiction and patriarchal culture, can be expressed. Thus, the rupturing of traditional forms becomes a political act, and the feminine narrative resulting from such rupture is allied with the feminist project. ("Contexts and Continuities" 4)

Here "assailing the social structure" and "producing an alternate fictional space" are understood as mutually reinforcing endeavours: in other words, aesthetic experiment is equated with radical politics. In the Preface to their 1989 collection Friedman and Fuchs 
described their task as "archaeological and compensatory" and situated it within "one of the important and active projects of feminist literary criticism, the recovery and foregrounding of women writers" (4). The under-representation of experimental women writers in more recent anthologies would seem to suggest that this "archaeological and compensatory" (4) work is far from redundant. In this context a publication devoted to contemporary experimental women writers (such as this special issue of Contemporary Women's Writing) might be seen as forging a kind of archive for the future: in this way, the contemporary could be conceived as a future past and its preservation serve as a guarantor against future forgetting. Complex discourses of temporality are at work here, in the promise both to transform orthodox history (evident in the "exploding", "assail[ing]" and "rupturing" which are so suggestive of the language of the historical avant-gardes) and to recover, repair and redress lost literary histories.

However, if experimental women writers, both past and present, are being marginalised or overlooked in literary fields they would appear to be the object of renewed interest elsewhere. In the spring of 2013 a significant British cultural institution hosted two symposia dedicated to exploring the legacy of a recently deceased pioneer of experimental writing in English, and the growing profile of a living writer whose work is beginning to be incorporated into emerging canons of narrative innovation: Christine Brooke-Rose and Chris Kraus respectively. Brooke-Rose is an author whose significance is recognised both in Breaking the Sequence: Women's Experimental Fiction (1989) and The Routledge Companion to Experimental Literature (2012), where she features under a variety of taxonomic headings, including proceduralism, metafiction, postmodernism, concrete writing and multimodal literature. While her name seems not to be forgotten when canon-forming lists are compiled, she was nevertheless described in an obituary by Natalie Ferris in 2012 as both "one of 
Britain's foremost experimental writers" and "one of the most deplorably neglected" (n.pag.). Chris Kraus, the object of the second symposium, is an American writer, film-maker and academic whose non-fiction novels combine life writing, art theory and critical reflections on neo-liberal economics and post 9/11 politics; defining motifs include a fascination with abjection, especially in relation to her own sexuality, and a preoccupation with marginality, particularly in relation to the hierarchies of academic prestige. What is significant about these events is that both were hosted by the Royal College of Art. Founded in 1837 and granted a Royal Charter in 1967, the RCA has been at the forefront of innovative British art, design and fashion. RCA graduates Peter Blake and David Hockney were at the heart of the Pop Art explosion in the 1950s and 1960s, and in the 1990s alumni such as Tracey Emin, Gavin Turk and Jake and Dinos Chapman were leading figures in what came to be known as the Young British Artist movement. Moreover, the symposia on Brooke-Rose and Kraus were hosted by the department of Critical Writing, which has become a significant institutional locus for debates about the expanding field of 'art writing'. A diverse and diffuse field which in many ways defies categorisation, 'art writing' nevertheless broadly represents what John Douglas Millar has described as a "bibliophile tendency" (“Art / Writing" n.pag) in contemporary art practice: that is, an interest in writing as an art practice and in the printed book as an art object. Crucially, the production, distribution and reception of this writing are situated in the art world, rather than in literary publishing contexts.

In this context, this article has two key aims: firstly, to provide some frameworks for reflection on the very concept of the 'contemporary' and its conjunction with the 'experimental' and, secondly, to explore a case study in the emergence of new experimental writing by women, with a focus on Chris Kraus. Contemporary literature-whether experimental or otherwise-is more than fiction which is being written and read now; indeed, 
the very concept of the 'contemporary' as a cultural category has a history. Moreover, the contemporary literary culture which is currently dominant can be understood as the product of a specific set of economic, historical and cultural conditions - conditions which are not necessarily receptive to the fostering of experimental writing. This article will reflect on the emergence of the 'contemporary' as a conceptual and periodising category, the construction of 'contemporary literary culture' in the late twentieth century and the concurrent formation of 'contemporary women's writing.' In recent years a number of critics and writers have given voice to a perception that the art world is becoming the refuge for experimental writing in a publishing context where the economic imperatives of the literary culture industry appear to prevail. Indeed, in an essay published by Art Monthly in 2011, Millar suggested that "while academic and creative disciplines cross-pollinate in the art world, they seem increasingly estranged in the literary world. The result is that the influence of experimental and avant-garde fiction waxes in the world of art while it wanes in the world of publishing" (“Art / Writing" n.pag.). It is striking to note that while Chris Kraus is increasingly identified as a leading experimental writer in art world contexts her profile remains (to date) less known in literary circles; this article will conclude by reflecting on the convergence of some distinctive enabling conditions for contemporary experimental women's writing outside of the literary publishing world. The UK reception of Kraus as an American author prompts interesting questions about the significance of national contexts when considering networks for the dissemination of experimental writing. A comparative analysis of UK and US publication contexts and reader communities is beyond the scope of this article; however, the key detail for the purposes of this analysis is the fact that Kraus's writing has found its way to UK readers via the transatlantic tracks of the art world, rather than the globalised pathways of the publishing industry. 


\section{The Contemporary}

The contemporary is a periodising term but a rather peculiar one since its object is constantly receding: Virginia Woolf will always be modernist, but Angela Carter will not always be contemporary. Where other periodising terms are employed with the benefit of hindsight and from the standpoint of the future, in its purest form the contemporary describes a condition in which the moment of cultural production and reception are identical and in which text and reader alike are the product of the same cultural moment. At first sight the contemporary may seem to be an ahistorical term since it appears to reside in the "perpetual present" (Jameson, 179). In his 2013 book Anywhere Or Not At All: Philosophy of Contemporary Art, Peter Osborne has suggested that "the root idea of the contemporary" is "a living, existing, or occurring together "in' time" (22) adding that "to claim something is contemporary is to make a claim for its significance in participating in the actuality of the present" (2). "Perpetual present" is, of course, a phrase made famous by Fredric Jameson in his Marxist critique of the postmodern condition; he suggests that we are condemned to live in it. However, for those fascinated with the study of the contemporary its richness resides in its status as crucible of the near but as yet unfixed future; in its analysis we can see the forces at work in the making of possible future histories, including forces implicated in inequalities of power. Moreover, the concept of the contemporary-as applied to culture and the arts-itself has a history. The contemporary as we currently understand it did not always exist and it is not impossible that its current dominance may, at some point, come to an end; the emergence of new period markers such as "post 9/11" and "twenty first century" might seem to suggest that the contemporary has indeed been surpassed. In his history of contemporary art, Osborne suggests that it is a specific product of the post-war settlement, arguing that, "[i]t was only after the Second World War, however, that it began to acquire its current historical and critical connotations through its use, first as a specification of, and then in contrast to, 
periodizing uses of 'modern'” (15). In other words, the term 'contemporary' was employed to signify a new way of engaging with modernity and a departure from the 'modernism' associated with the avant-garde movements of the early twentieth century, such as Dada, Surrealism, Constructivism and Futurism. So, according to Osborne, the contemporary was not simply "the most recent modern" (16) but rather it suggested a new way of conceptualising the present, one aligned with the social and economic modernity of the post war period, but perhaps divested of the more transgressive energies and subversive temporality of the modernist avant-garde.

The establishment of cultural institutions to foster and promote contemporary arts and culture further signified the entry of the contemporary into national cultural life. Osborne offers the following vignette:

When the Institute of Contemporary Arts (ICA) was founded in London in 1946, for example, it was very up to date indeed. Doubly and paradoxically so, in fact, in so far as it both fed off the residual energies of the pre-war avant-garde [. . .] and took a step back from that avant-garde's ruptural historical futurity into the more expansive present of a new beginning. (16)

The founders of the ICA, who included two leading British advocates of Surrealism, Roland Penrose and Herbert Read, are reputed to have "resisted an initial impulse to become a Museum of Modern Art for London, preferring instead to position [the ICA] at the forefront of art and culture" (Institute of Contemporary Arts). Indeed, in the 1950s the ICA championed proto-Pop Artists Peter Blake and Richard Hamilton and from the late 1960s became renowned as a live performance venue, not only showcasing new wave music and 
film but also giving a stage to contemporary artists to share their work with public audiences through interviews and talks. In other words, it contributed to the expansion of spoken word events which are now such an integral feature of contemporary cultural-and literarymetropolitan life.

The advent of the contemporary would appear to mark the moment when modernism-the movement so inextricably associated with the condition of modernity and with the experimental impulse in literary production-becomes historical. What becomes clear from these reflections is that the concept of the contemporary is deeply implicated in the fate of modernism, a diverse movement but one broadly characterised by its commitment to innovation, its often oppositional stance in relation to social and cultural norms and its ambivalent and sometimes critical response to the advent of mass culture and what Theodor W. Adorno and Max Horkheimer called the 'culture industry'. So while there has always been literature whose publication occupies the same time frame as its consumption - which is one way of defining contemporaneity in literary studies - this literature has not always been described as 'contemporary'. Indeed, in the introduction to his 2006 Concise Companion to Contemporary British Fiction, James F. English observes that “[u]ntil quite recently, it was common practice to treat "contemporary" British fiction as synonymous with the fiction of the entire post war period ... It was as though the fiction of postwar Britain had never actually been contemporary until now [emphasis added]" (1-2). The 'contemporary', then, is a relatively recent invention and one originating in very specific historical and cultural contexts: not merely a conceptual category in the academy but a commodity in a broader cultural marketplace. As such, it is important to recognise the role of markets, economies and infrastructures in constructing contemporary literary fiction as we know it. 


\section{Contemporary Literary Fiction}

In her 2009 book Marketing Literature: The Making of Contemporary Writing in Britain, Claire Squires argues that, "the last two decades of the twentieth century" saw "an intensification in the marketing activity surrounding literary fiction" (6); indeed, the British literary market provides a case study in trends which are not restricted to UK contexts. These changes can be attributed to a range of factors, including the entry of global multi-media conglomerates into the publishing world and a retail environment transformed by the demise of the Net Book Agreement. Simone Murray, in her 2012 book The Adaptation Industry: The Cultural Economy of Contemporary Literary Adaptation, refers to "significant structural, technological and cultural changes" (20) in the book world since the 1980s. Murray lists a number of factors as contributing to this changed landscape:

the growth of corporatisation and conglomeration from the early 1980s; the revolutionary impact of digital technologies on all phases of book production, distribution and retailing; the eclipse of the editor by the agent as the author's literary mentor and champion; the elevation of book prizes in promotional campaigns by English-language publishers (notably the (Man) Booker Prize); the creation of international book fair and writers' festival circuits; and the marked growth of 'subsidiary' rights in non-book media as a feature of standard author-publisher contracts during the period. (20)

This period also sees the launch of key arbiters in the construction of literary taste in relation to contemporary fiction. In 1968 Tom Maschler, then a publisher working at Jonathan Cape, secured the sponsorship of a multinational agribusiness conglomerate for a new literary prize to "reward the best novel of the year written by a British or Commonwealth writer" (Man 
Booker Prize). It is worth noting the novelty of the criteria for this award, and how its success has served to significantly accelerate the processes of opinion shaping and canon forming where new fiction is concerned. The test of time has traditionally been understood as playing a central role in the emergence of novels and authors into the literary canon; the Booker Prize dispensed with the criterion of hindsight and effectively offered to produce new canons of literary fiction on an annual basis. Moreover, its success has triggered a proliferation of new literary prizes. Indeed, 2013 saw the launch of two new awards, both seemingly originating in the controversy surrounding the 2011 Man Booker Prize award, when the Prize panel Chair, Dame Stella Rimington, suggested that "readability" would be a key judging criterion. In 2013 the first Goldsmiths Prize was awarded. The Prize aims to "celebrate the qualities of creative daring associated with the University and to reward fiction that breaks the mould or opens up new possibilities for the novel form" (Goldsmiths Prize website). Sponsored by the New Statesman the Prize takes its name from a University closely associated with the Young British Artist movement of the 1990s. 2014 saw the first award of the Folio Prize. It was judged by a self-appointed academy, which declaring the Prize "the first major English language book prize open to writers from around the world" (The Folio Prize). It may seem no coincidence that in September of 2013 the Man Booker Prize Foundation made a historic decision to break with its tradition of championing UK and Commonwealth fiction by extending eligibility to American authors. In 1979, 10 years after the first award of the Booker Prize, the launch of two new literary periodicals, Granta and the London Review of Books, created further publishing platforms for new writers and fostered new generations of author-reviewers. Neither are mass market publications but both have exercised significant influence on contemporary literature, with the more market conscious Granta quite explicitly seeking to play a leading role in how canons of contemporary fiction are defined. Granta's Best of Young British Novelists editions (published in 1983, 1993, 
2003 and 2013) are clearly an attempt to forge new literary generations and have certainly contributed to the ascendancy of a particular generation of largely male British novelists, including Martin Amis, Julian Barnes, Kazuo Ishiguro, Ian McEwan and Salman Rushdie.

The latter part of the twentieth century has also seen the growth of creative writing MAs and the proliferation of contemporary fiction in A Level and University curricula, creating new synergies between academia and literary fiction. Kazuo Ishiguro was one of the first recipients of the University of East Anglia MA in Creative Writing; he has been nominated for the Booker Prize on four occasions (winning in 1989 with The Remains of the Day) and is one of a small number of writers who have been named Best Young British Novelist by Granta more than once. ${ }^{1}$ It seems fair to speculate on the ways in which the preferences of literary prize panels might be shaping literary publishing strategies and the extent to which creative writing pedagogies may be contributing to new kinds of self-referential literary cultures in which authors, critics and researchers alike share identical academic frames of reference. All of these forces-whether market, industry or academic-exist in a complex relationship of critical complicity; they arguably conspire to produce something that is at once a market commodity, canon of authors and titles, and a category of literary study: namely, contemporary literary fiction. In other words, contemporary literary fiction is not simply non-genre fiction which is being published now. It is a particular genre of literary fiction whose literary properties and authorial signature make it more likely to be short-listed for prestigious literary prizes, optioned for adaptation for the screen and able to mobilise market signifiers of the literary (such as coverage in the quality broadsheet press), while also attracting more than a minority readership. 
Women's writing has emerged over the last few decades as a dynamic field of literary research and as a thriving market in literary publishing; the literary achievements of women, and the purchasing power of female readers, are arguably integral to the contemporary literary market. Here I want to reflect on the convergence of the contemporary as a genre of fiction with a significant movement for social and cultural change.

\section{Contemporary Women's Writing}

It is interesting to note that the emergence of the category of contemporary writing-both in academic and industry contexts-coincides with the Second Wave of the women's movement and its legacy. Hence the period it denotes could equally be described as one characterised by the impact of feminism in broader culture. Women writers who came to note as 'contemporary' at this time were women whose lives and writing bore the imprint of the women's movement, whether they identified as feminist or not. Feminist activism inspired both the production of ground--breaking works of literary fiction and radical interventions in the very infrastructure of the literary establishment. The emergence of feminist presses, and their contribution to the construction of the canon of historic and contemporary women writers, was a key enabling condition for the publication of women's writing. The first board meeting of the women's publishing press, Virago, was held in 1973 by Carmen Callil, Rosie Boycott and Marsha Rowe. Boycott and Rowe were founders of the feminist magazine, Spare Rib, and this new feminist imprint was initially registered as Spare Rib Books. When the first edition of Spare Rib was published in 1972 some newsagents, including leading British retailer WH Smiths, refused to stock it; a feminist publishing imprint might have been expected to face similar challenges in reaching a mainstream readership. However, as Simone Murray has written in her 2004 book Mixed Media: Feminist Presses and Publishing Politics, from its inception Virago "perceived itself simultaneously 
both as a commercial publishing house and as an intrinsic part of the British women's liberation movement" (32). Murray goes on to observe that: "Virago's belief in the mass appeal of eye-catching, well-designed titles is intrinsically linked to its feminist beliefs: the potential for feminist ideas - well-packaged and well-marketed - to take root in mainstream society was the wellspring of Virago's birth" (Mixed Media, 55). The Virago Modern Classic list, first launched in 1978 with a reprint of Antonia White's 1933 novel Frost in May, proved a stroke of feminist marketing genius. As Murray notes: "Relying on a list of forgotten women's classics that mainstream houses had allowed to drop out of print, Virago was able to capitalise on second-wave feminism's thirst for antecedents by producing feminist-informed texts in attractively packaged trade paperback formats" (Mixed Media, 69).

The category of the contemporary has, then, a particular, if implicit, historical meaning in relation to the construction of contemporary women's writing. Angela Carter is surely the author who most exemplifies this particular iteration and its paradoxes. When she died at the age of 51 in 1992, Carter had been a pivotal figure in British literature since the late 1960s; she is now recognised as one of the most influential writers of her generation. On the one hand, Carter seems the contemporary woman writer par excellence, her writing not merely reflecting but directly informing the radical cultural politics of the era in which contemporary fiction as we know it was forming; indeed, her work and image were at the forefront of the relaunch of Virago in 1996, following its purchase by Little, Brown. On the other hand, the majority of her work was published between the late 1960s and mid 1980s; in this sense it could be argued that her work cannot strictly be considered contemporary. If her work still strikes us as contemporary this is not just because her themes and strategies continue to have relevance for many readers; it is perhaps also because her identity as a writer in the public 
eye was forged simultaneously with the emergence of contemporary fiction as we know it, such that she seems an eternal contemporary.

Entry into the mainstream is one of the great achievements of cultural feminism, but the legacy of this integration is one whose problems and paradoxes have preoccupied significant feminist energy in recent years. An interest in popular culture, including popular fiction, has been a defining feature of feminist literary and cultural studies since its inception. From studies of romance fiction and its readers, through reconsideration of the middlebrow novel to work on 'chick lit' and 'chick flicks', feminist scholars have refused to accept the denigration of women as cultural consumers and the critical neglect of cultural forms directed at a mass female market. ${ }^{2}$ However, while this endeavour once entailed the discovery of hidden feminist meanings in outwardly conservative forms, it now contends with the explicit appropriation of feminist ideas concealing reactionary political subtexts. Indeed, while mainstream publishers have been quick to capitalise on the popularity of women's writing and exploit the market for postfeminist genres such as 'chick lit', inequalities still persist. The Man Booker Prize has attracted criticism for its failure to recognise the achievement of leading contemporary women writers. The Booker Prize Foundation launched the "Best of Beryl" online reader's poll as a kind of public penance and posthumous apology for its failure to recognise the work of the late Beryl Bainbridge, whose novels were short-listed on four separate occasions. Indeed, the Orange Prize for Fiction (now the Baileys Women's Prize for Fiction) was launched in 1996 to redress the shortcomings of existing literary prizes. The 2013 VIDA Count, an annual survey of the gender representation in literary publications, found that in leading titles in the US and UK up to $80 \%$ of coverage was devoted to, or written by, male authors: the percentage of female authors reviewed or reviewing was $27 \%$ in 
the Times Literary Supplement, 23\% in McSweeneys, 21\% in the London Review of Books and $20 \%$ in the New York Review of Books. ${ }^{3}$

The question remains as to who will champion writing more concerned with experiment and innovation than with mass market readerships, film rights or the literary celebrity circuit. Chris Kraus has referred to writing as one of the "orphaned humanities" and suggests that it has "migrated into the ever-more-amorphous realm of the 'art world"' (Latimer 62) in reaction to the "increasingly hegemonic" (Latimer 61) culture industry. Indeed, one of the most recent anthologies of experimental writing by women-I'll Drown My Book:

Conceptual Writing by Women (2013)-conceives of writing as an art practice rather than a branch of literature. While 'art writing' is a term which has been broadly applied to a diverse range of artistic practice in relation to the spoken or printed word, 'conceptual writing' is much more closely defined by its proponents and practitioners. Craig Dworkin, who is credited with coining the term 'conceptual writing,' argues that it refers both to "literary writing that could function comfortably as conceptual art" and "the use of text in conceptual art practices" ("The Fate of Echo" xxiii). More specifically, Dworkin proposes that it is characterised by a departure from originality as traditionally understood; it is informed by “the realisation one doesn't need to generate new material to be a poet: the intelligent organisation or reframing of already extant text is enough" ("The Fate of Echo" xlix). I'll Drown My Book: Conceptual Writing by Women (2013), edited by Caroline Bergvall, Laynie Brown, Teresa Carmody and Vanessa Place, was published in part as a response to the under-representation of women writers in Craig Dworkin and Kenneth Goldsmith's Against Expression: An Anthology of Conceptual Writing (Evanston, IL: Northwestern UP, 2010). I'll Drown My Book includes some familiar names from literary canons of experimental writing by women-such as Kathy Acker, M. Nourbese Philips and Rachel Blau DuPlessis- 
but also leading figures in the conceptual writing movement, such as Jen Bervin and Kim Rosenfeld. Moreover, its publishers, Les Figues Press in Los Angeles, California, sought support not from mainstream publishers but from crowd-sourcing; it was made possible by public subscription through Kickstarter, the public funding platform for creative projects. ${ }^{4}$ The relationship between conceptual writing-as one of the most recent iterations of the formalist experimental writing tradition-and gender politics extends beyond questions of canon formation. Conceptual writing is often playful (employing literary constraints reminiscent of the Oulipo), usually impersonal (rather than expressive) and frequently demonstrates an interest in the quotidian experience of everyday life in late capitalist economies; Kenneth Goldsmith's 2003 Day transcribed the entire contents of an edition of the New York Times while The Weather (2005) and Traffic (2007) applied the same method to broadcast reports. By contrast, in 2010 the writer and criminal appellate attorney Vanessa Place published Tragodia 1: Statement of Facts (2010), which reproduced graphic and disturbing statements from the proceedings of rape trials. Presented without rationale or interpretative framework, Statement of Facts tested the ethical and political limits of conceptual writing as a practice. A similarly forensic attitude to questions of sexuality and power is evident in the work of Chris Kraus whose writing can be seen as an extension of her art practice as a performer and film-maker; where conceptual writing tends to be impersonal and formalist, Kraus's work is highly self-reflexive and discursively hybrid, combining autobiographical fiction and art criticism. I wish to conclude with some reflections on her first novel, I Love Dick (1997), which has acquired cult status in art world contexts, reaching its readers through routes which bypass the mainstream literary publishing apparatus. Kraus both performs and documents her life experiences in a narrative whose cuts and jumps more closely resemble the language of film than the conventions of realism; the abject experience 
of an unrequited infatuation is anatomised as an experiment through which the rituals of heterosexual romance are exposed.

\section{“On our knees": a case study in Chris Kraus}

Chris Kraus is an American author, film maker and academic whose publications include $I$ Love Dick (1997), Aliens \& Anorexia (2000), Torpor (2006) and Summer of Hate (2012) as well as collections of art criticism, including Video Green: Los Angeles Art and the Triumph of Nothingness (2004) and Where Art Belongs (2011). Kayla Guthrie places Kraus within a tradition of feminist cultural production which encompasses literary and art practice from the modernist era to the present: "Kraus is associated with a provocative femininity rooted in the New York of the '70s and '80s, whose other representatives include Kathy Acker, Nan Goldin, and Eileen Myles, with precedents in the $20^{\text {th }}$ century avant-garde like Virginia Woolf, Gertrude Stein, and Urnica Zurn” (n.pag.) More specifically, Kraus’s work can be situated within a lineage of women writers and artists who have worked with their own lived experience as their creative subject matter. Indeed, Kraus's writing is crucially informed by the question which she attributes to the artist, Hannah Wilke: "If women have failed to make "universal" art because we're trapped within the "personal," why not universalize the "personal" and make it the subject of our art?" (I Love Dick, 211, emphasis in original). Marginality is a key motif in Kraus's self-reflexive writing, including her own artistic marginality as a 'failed' film-maker, her academic marginality as the wife of a celebrated champion of French philosophy and the marginalisation of women's and feminist art practice more broadly. Marginality also describes the publication provenance of her writing, an independent academic imprint rather than a major literary publishing house. 
Hannah Wilke (1940-1993) is one of a number of women artists whose lives and works are interwoven into the fabric of Kraus's texts. Wilke, an American artist whose practice encompassed painting, sculpture, video and performance, is perhaps best known for her photographic body art, including her 1974 "S.O.S - Starification Body Series" in which she imprinted her body with small vulval sculptures made of chewing gum. A pioneer in feminist art practice, Wilke's use of her own naked body nevertheless attracted accusations of narcissism and exhibitionism which continue to be made against any female artist or writer who uses her own body or life as a creative resource. The life and writings of the French philosopher, Christian mystic and political activist Simone Weil (1909-1943) are a central concern in Kraus's 2000 book Aliens \& Anorexia, in which Kraus recounts her struggles to find an audience for a film whose title is borrowed from one of Weil's studies: Gravity \& Grace. Weil's gestures of solidarity with the oppressed-fighting in the Spanish Civil War despite her pacifism, adopting a restricted diet which is reputed to have contributed to her early death-attracted ridicule rather than respect. For Kraus, Weil's reputation is symptomatic of a reluctance to tolerate transgressive expressions of individuality by a woman: "[Weil] was a crazy modernist like Artaud, Celine, Bataille, but as a female her "I" has been pathologised [...] her "I" was never read as universal and transparent" (Frimer, n.pag.). Indeed, Kraus's writing often provides a space for reflections on the erasure of women's experimental art from the history of the avant-garde: "Dear Dick, I'm wondering why every act that narrated female lived experience in the 70s has been read as "collaborative" and "feminist". The Zurich Dadaists worked together too but they were geniuses and they had names" (I Love Dick 150). The addressee of the preceding observation is the ostensible object of an infatuation which forms the basis of Kraus's first book, I Love Dick, published in 1997; more accurately, 'Dick' becomes the pretext for an art project 
through which the narrator, 'Chris', documents her life through diaries and letters as a form of "Case Study" (97, 153, 155).

As the author Eileen Myles puts it, in a preface to the 2006 edition of I Love Dick: "Her living is the subject, not the dick of the title, and while unreeling her story she deftly performs as art critic, historian, diarist, screenwriter of an adult relationship, performance artist” (15). 'Chris', 'Sylvère' and 'Dick' are fictionalised versions of Kraus, her husband (cultural theorist and founder of Semiotext(e), Sylvère Lotringer) and the unwitting object of her sexual obsession (whose real life counterpart is identified by Joan Hawkins, in the Afterword to the 2006 edition, as Dick Hebdige, the leading British born cultural theorist). Chris enlists her husband into the fantasy and the collaboratively written letters which they compose initially serve to rekindle their marital intimacy. The literary sensibility at work in this epistolary exercise is foregrounded through allusions to Gustave Flaubert's Madame Bovary (1856), a novel which established adultery as one of the defining narrative motifs of the modern novel. In a letter ostensibly authored by Sylvère, addressed to Dick but written in the guise of 'Charles Bovary,' one man taunts the other as the mere product of a marital sexual fantasy: "Emma and I created you out of nothing, of very little, and in all fairness, You owe us everything. While you flounder in your daily life we have built you up as a truly powerful icon of erotic integrity" (112). However, there is a possibility that multiple imposture is at play in this instance of ironic intertextuality: namely, that the letter is itself authored by 'Chris' and that both men are scripted into roles defined by her narrative. Indeed, 'Chris' leaves her husband midway through the narrative: "Here's the formulation: I got together with Sylvère because I saw how I could help him get his life together. I'm drawn to you [Dick] cause I see how you can help me take my life apart" (132). 
The experience of female abjection, particularly in relation to sexual desire, is a recurring motif in Kraus's writing and I Love Dick is no exception. Throughout her writing, Kraus's depiction of her passive role in sado-masochistic sexual encounters with men encountered through online dating sites serves as a prism through which to examine the power play at work in heterosexual relationships more widely. This insight is typified in the following scenario recounted in "Emotional Technologies", an essay which features in her 2000 collection of art criticism Video Green: Los Angeles, Art and the Triumph of Nothingness:

He'd instructed me to undress at 7.30 and kneel, naked, by the phone. Sometime within the next half hour he' $\mathrm{d}$ call with more instructions. The phone rang at 7.59 and well, I found this pretty fucking witty. How many times have I, has every heterosexual female in this culture, spent evenings mooning around our houses and apartments, psychically stripped bare and on our knees while waiting for "his" call? Why not take the courtship ritual literally? (95) Myles describes I Love Dick as a "remarkable study in female abjection" (13) but crucially one which "turn[s] female abjection inside out and aim[s] it at a man" (15). Indeed, in her essay "Manic Impositions: The Parasitical Art of Chris Kraus and Sophie Calle," Anna Watkins Fisher draws parallels between Kraus's I Love Dick and the artist Sophie Calle's 2007 art work, Take Care of Yourself, suggesting that both make "surrogate victims" (224) of actual men. In Take Care of Yourself, Calle excised the final line of an email message from a former lover terminating their relationship and circulated it to over a hundred women, collating their interpretations and presenting them in an art installation exhibited at the 2007 Venice Biennale. Fisher suggests that Kraus and Calle "mobilize epistolary and diaristic practices, traditionally seen as benign feminine literary forms, to challenge heterosexual romance's complicity in women's abjection" (224). Where orthodox art history erases the lives and works of female artists, these artworks bring into the public arena the intimate lives 
of actual men to serve as exempla in the documentation of heterosexual politics; fictionalised or anonymised, these men are not the target of this art but rather its vehicle, unwitting performers in an artwork which exposes the role-playing which shapes the experience of intimate lives. Indeed, the performative nature of Kraus's writing has been noted by more than one commentator, as well as by the author herself. Guthrie suggests that Kraus is "theorizing and performing femininity in the same monologue" (n.pag.) and Jen Kennedy draws parallels between Kraus's writing and her film-making, suggesting that: "In many ways, Kraus's films are a first attempt to do what she later accomplishes in her writing: to actualize a mode of performative criticism that breaks down the separation between ideas and emotions" (Henry, n.pag.). In an interview with the American author Sheila Heti, Kraus herself makes an analogy with her first creative vocation, when she observes: "As an actress, you're living something through the duration of the play and its geography. I've always seen writing the same way. It's like somehow I'm moving through the terrain of the book as a performer, but this time I'm transcribing” (Heti n.pag.).

This complex relationship between authorship, autobiography and performance underlines the way in which Kraus's writing escapes categorisation, especially in relation to the generic boundaries between fiction and non-fiction, the novel and the memoir; as such it might present problems for a publishing industry which relies on genre to enable market segmentation. As Joseph Henry suggests in Blouin Artinfo, she has "established a writerly paradigm that took as its starting point the interweaving of personal experience, aesthetic evaluation, and socio-political history" (n.pag.). Writing in the Art Book Review, Paul Pescador argues that "I Love Dick is not a memoir, but performs as one. Both fiction and nonfiction simultaneously, the narrative of the book dissolves personal experience and constructed moments into one another" (n.pag.). Moreover, it is notable that the production 
and reception of Kraus's work has taken place through routes outside of conventional literary publishing: its origins are situated in the context of academic publishing and its reception is characterised by an art world readership. Kraus's books are published by Semiotext(e), an independent press established by Sylvère Lotringer in 1973 and renowned for introducing French theory to American audiences. As Rolando Pérez argues in "Love and Hatred of 'French Theory' in America", the Foreign Agents imprint of Semiotext(e) "single-handedly introduced the most important French thinkers to America, and in the process changed the way many of us did philosophy, cultural studies and literary theory afterwards" (para 11, emphasis in original). Moreover, in their history of the press, based on interviews with Lotringer and Kraus, Henry Schwarz and Anne Balsamo suggest that it was established with the express intent of bypassing the gate-keeping function of more conventional academic and literary publishers:

In an era when "small press" and "speciality journal" usually denote institutionally supported projects, with their readership confined almost wholly to academics and their funding coming almost exclusively through the university, Semiotext(e) began its publishing career with a conscious strategy to short circuit this complicity between radical culture and conservative institutions of taste. (206)

Enjoying an unusual autonomy, its lists were nevertheless affected by the idiosyncrasies of its editorial tastes; Schwarz and Balsamo note that the absence of feminist theory from the first 15 years of its history constitutes a "glaring blindspot" (212) which the Native Agents series, launched by Kraus, began to redress. Kraus is not the only innovative contemporary writer to have emerged from the art world. British author Tom McCarthy's debut novel Remainder was first published in 2005 by a small art publisher, Metronome Press, based in Paris, having been rejected by mainstream literary publishing houses in the UK; McCarthy has suggested that "[i]n the current climate art has become the place where literary ideas are received, 
debated and creatively transformed" (Millar, "Art/Writing” n.pag.). However, the perception that the literary world has abdicated its responsibility to recognise and reward experimental writing would seem to be challenged by the recent award of major literary prizes to established and emerging experimental women writers: in 2013 the acclaimed American writer Lydia Davis was awarded the International Man Booker Prize and the Irish writer Eimear McBride was awarded the inaugural Goldsmiths Prize for Literature (2013) and Baileys Women's Prize for Fiction (2014) for her debut novel A Girl is a Half-Formed Thing. Nevertheless, the construction of the art world as the new champion of experimental writing is a phenomenon which is perhaps symptomatic of the anxieties and opportunities generated by significant shifts in the literary publishing industry in recent decades.

The context of Chris Kraus's developing profile as a writer is characterised by the convergence of some distinctive enabling conditions for experimental writing: a mutually supporting proximity between academia and experimental writing, a relatively autonomous network of production and reception and an understanding of writing as an art practice rather than a branch of literary production. In I Love Dick Kraus writes: "Chris was not a torture victim, not a peasant. She was an American artist, and for the first time it occurred to her that perhaps the only thing she had to offer was her specificity. By writing Dick she was offering her life as Case Study" (97). The very specificity of Kraus's profile as a writer means that the 'case study' she presents is more particular than representative. However, her 'case' is certainly illustrative of the fact that experimental writing by contemporary women authors is emerging in spaces other than those legitimised by the contemporary literary publishing industry. Moreover, the continuity between feminist experimental practice across the arts which is manifest in Kraus's writing may be instructive in reminding us that the 'literary' may itself be a category too narrow to accommodate all that is innovative in the written word. 
To conclude, Christine Brooke-Rose's reflections on the condition of being an 'experimental woman writer' in her essay “Illiterations" still seem pertinent: “Three words. Three difficulties" (Brooke-Rose 55). I have suggested that to these 'three difficulties' we may add a fourth: the contemporary. In the context of this article these difficulties have been explored through critical reflection on the definition of the contemporary, its value as a historicising concept and its uses as a marketing category. It can be argued that the construction of contemporary literary fiction has provided a prominent cultural platform for new generations of women writers; however, it has also been suggested that the mandates of the publishing industry can be at odds with the championing of new experimental forms and voices. I have sought to provide some frameworks for thinking critically about the construction of contemporary literary fiction and the implications of this construction for the visibility - or otherwise - of experimental writing by women authors. More than a mere marker of the present, the 'difficulties' prompted by the contemporary as a category of literary analysis may prove productive for reflecting on the history and future of writing by women.

\section{Works Cited}

2013 VIDA Count. Web. < http://www.vidaweb.org/category/the-count/the-2013count/page/2/>. 28 May 2014.

Adorno, Theodor W. and Max Horkheimer. Dialectic of Enlightenment (1944). Trans. John Cumming. London: Verso, 1977.

Bergvall, Caroline and Laynie Brown, Teresa Carmody and Vanessa Place, eds. I'll Drown My Book: Conceptual Writing by Women. Los Angeles: Les Figues, 2013. 
Black, Noel and Eileen Myles. Interview. The Brooklyn Rail. 3 May 2013. Web.

$<$ http://www.brooklynrail.org/2013/05/poetry/eileen-myles-and-noel-black> 8 May 2013.

Bray, Joe, Alison Gibbons and Brian McHale (eds). The Routledge Companion to Experimental Literature. London and New York: Routledge, 2012.

Bray, Joe, Alison Gibbons and Brian McHale. "Introduction.” Bray, Gibbons and McHale 118.

Brooke-Rose, Christine. "Illiterations." Friedman and Fuchs 55-71.

Dworkin, Craig, "The Fate of Echo". Dworkin and Goldsmith xxiii-liv.

Dworkin, Craig and Kenneth Goldsmith. Against Expression: An Anthology of Conceptual Writing. Evanston, IL: Northwestern UP, 2010.

English, James F. "Introduction: British Fiction in a Global Frame." A Concise Companion to Contemporary British Fiction. Malden, Mass; Oxford: Blackwell, 2006. 1-6.

Ferris, Natalie. “Christine Brooke-Rose: the great British experimentalist you've never heard of." The Guardian. 23 March 2012. $<\mathrm{http}: / /$ www.theguardian.com/books/2012/mar/23/christine-brooke-rose $>$

Fisher, Anna Watkins. "Manic Impositions: The Parasitical Art of Chris Kraus and Sophie Calle." Women's Studies Quarterly 40: 1/2 (2012): 223-235.

Friedman, Ellen G. and Miriam Fuchs (eds). Breaking the Sequence: Women's Experimental Fiction. Princeton, New Jersey: Princeton UP, 1989.

Friedman, Ellen G. and Miriam Fuchs. "Contexts and Continuities: An Introduction to Women's Experimental Fiction in English.” Friedman and Fuchs. 3-51.

Frimer, Denise. "Chris Kraus in Conversation with Denise Frimer.” The Brooklyn Rail. Web. 10 April 2006. <http://www.brooklynrail.org/2006/04/art/chris-kraus-inconversation-with-denise-frimer> 1 May 2014. 
Goldsmiths Prize. Web. 22 May 2014. <http://www.gold.ac.uk/goldsmiths-prize/>

Guthrie, Kayla. "Performing is Storytelling: Q+A With Chris Kraus." Art in America. Web.

22 June 2011. <http://www.artinamericamagazine.com/news-

features/interviews/chris-kraus-real-fine-arts/> 1 May 2014.

Henry, Joseph. "The Art of Failure: On the Films of Chris Kraus." Blouin Artinfo. Web. 1 July 2013. <http://www.blouinartinfo.com/news/story/923353/the-art-of-failureon-the-films-of-chris-kraus> 1 May 2013.

Heti, Sheila with Chris Kraus. "Politics is topical - it's what's happening now, and we can either respond in the present or avoid it." The Believer. Web. September 2013. $<$ http://www.believermag.com/issues/201309/?read=interview_kraus> 1 May 2014.

Humble, Nicola. The Feminine Middlebrow Novel, 1920s to 1950s: Class, Domesticity and Bohemianism. Oxford: Oxford UP, 2001.

Institute of Contemporary Arts. Web. <http://www.ica.org.uk/history>. 16 March 2014.

Jameson, Fredric. "Postmodernism and Consumer Society." Modernism / Postmodernism.

Ed. Peter Brooker. London and New York: Longman, 1992. 163-179.

Kraus, Chris. "Emotional Technologies" (2000). Kraus, Video Green 85-103.

Kraus, Chris. I Love Dick. Los Angeles: Semiotext(e), 2006.

Kraus, Chris. Video Green: Los Angeles, Art and the Triumph of Nothingness. New York: Semiotext(e), 1994.

Latimer, Quinn with Chris Kraus. "It's Very Sad, Really: Art Writing, Orphaning, Migration of the Humanities and (No) Information.” Mousse 39. (Summer 2013). Web. N.pag. $<\mathrm{http}: / /$ www.aaronvandyke.net/summer_readings/Kraus_Chris-interviewIt's\%20Very\%20Sad\%20Really-Mousse.pdf1> May 2014.

Man Booker Prize. Web. 22 May 2014. <http://www.themanbookerprize.com/> 
Millar, John Douglas. “Art / Writing,” Art Monthly 34 (9 September 2011). Web.

$<$ http://www.artmonthly.co.uk/magazine/site/article/art-writing-by-john-douglasmillar-september-2011> 22 May 2014.

Murray, Simone. Mixed Media: Feminist Presses and Publishing Politics. London: Pluto Press, 2004.

Murray, Simone. The Adaptation Industry: The Cultural Economy of Contemporary Literary Adaptation. New York and London: Routledge, 2012.

Myles, Eileen. "Forward: What About Chris." Kraus, I Love Dick 13-15.

Osborne, Peter. Anywhere Or Not At All: Philosophy of Contemporary Art. London and New York: Verso, 2013.

Pérez, Rolando. "Love and Hatred of "French Theory" in America." Borderlands 4:1 (2005) n.pag. Web. 28 April 2014.

Pescador, Paul. "I Love Dick: Review." The Art Book Review. Web. 11 December 2013. $<$ http://theartbookreview.org/2013/12/11/i-love-dick/> 1 May 2013.

Radway, Janice. Reading the Romance. North Carolina: North Carolina UP, 1984.

Rimington, Stella. 2011 Man Booker Prize Ceremony. Web.

$<$ http://www.themanbookerprize.com/feature/dame-stella-rimington $\% \mathrm{E} 2 \% 80 \% 99 \mathrm{~s}-$ speech-man-booker-prize-2011> 13 May 2013.

Schwarz, Henry and Anne Balsamo. "Under the Sign of Semiotext(e): The Story According to Sylvère Lotringer and Chris Kraus." Critique 37:3 (1996): 205-221.

Squires, Claire. Marketing Literature: The Making of Contemporary Writing in Britain. London: Palgrave Macmillan, 2009.

The Folio Prize. Web. <http://www.thefolioprize.com/>. 28 May 2014.

Whelehan, Imelda. The Feminist Bestseller: From Sex and the Single Girl to Sex and the City. London: Palgrave Macmillan, 2005. 


\footnotetext{
${ }^{1}$ Authors who have been named one of Granta's Best New British Novelists more than once include: Kazuo Ishiguro (1983 and 1993); Adam Mars Jones (1983 and 1993); A.L Kennedy (1993 and 2003); Zadie Smith (2003 and 2013); Adam Thirlwell (2003 and 2013).

${ }^{2}$ Key interventions include: Janice Radway, Reading the Romance (North Carolina UP, 1984); Nicola Humble, The Feminine Middlebrow Novel, 1920s to 1950s: Class, Domesticity and Bohemianism (Oxford: Oxford UP, 2001); Imelda Whelehan, The Feminist Bestseller: From Sex and the Single Girl to Sex and the City (London: Palgrave Macmillan, 2005).

${ }^{3}$ In 2013 the VIDA methodology was amended to include authors who identify as transgender; only one author was recorded.

${ }^{4}$ In an interview published in The Brooklyn Rail in 2013, Noel Black and Eileen Myles reflect on the extent to which the publication of I'll Drown My Book redresses the marginalisation of women writers but also the extent to which such strategies reinforce gender binaries. On the subject of her own omission, Myles comments: "I think the people who know me or read me don't entirely treat me as male or female. No matter what Vanessa [Place] says I think I'm not in her book because I'm not female. I'm something else" (Black, n.pag.).
} 